\title{
Aerial films and solar angles: Influences on silver sagebrush inventory
}

\author{
LIVIO FENT
}

Author is a resource information project coordinator and photographic scientist in the Resource Information Unit, Environmental Service-Prairie region, Alberta Environmental Protection, YPM Place $3^{\text {rd }}$ floor, $5308^{\text {th }}$ street South, Lethbridge, Alberta, Canada. T1J $2 J 8$.

\begin{abstract}
Aerial photos in Alberta are generally acquired according to topographic mapping and forestry specifications. The parameters for interpreting rangeland vegetation, such as silver sagebrush (Artemisia cana-Pursch), need to be explored and condensed into an operational specification. Five aerial films and 3 solar angles were evaluated by 7 photo interpreters to determine the optimal conditions for interpreting silver sagebrush at a scale of 1:20,000. Interpreter accuracy and preference are determined for the 2 experimental conditions as to determine operational specifications. Kodak Panatomic-X 2412 achieved the highest interpretation accuracies for silver sagebrush cover detection and plant density estimation $(91.0 \%$ and $94.4 \%$ respectively), while Kodak Aerochrome Infrared 2443 and Agfa Avicolor H100 performed best for estimating plant vigor $(\mathbf{9 2 . 7 \%}$ and $\mathbf{9 3 . 7 \%}$ respectively). Photo interpreters also chose Kodak Panatomic-X 2412 as the preferred film for interpreting silver sagebrush (7.7 on a scale of 10). Positive correlations were obtained between combinations of interpretation accuracy, interpreter film preference and photographic density range measurements, indicating the trends for higher accuracy and preference are associated with higher density ranges. Solar angles of $20^{\circ}, 37^{\circ}$ and $54^{\circ}$ were evaluated by photo interpreters with significant preference shown for $20^{\circ}$. Recommendations for modifying Alberta's air photo operational specifications to include high resolution (Kodak Panatomic-X) imagery and decreasing the acceptable lower boundary for the operational solar angle from 30 to $20^{\circ}$ for interpreting silver sagebrush at the 1:20 000 scale are proposed.
\end{abstract}

Key Words: Aerial photography, spectral sensitivity, film resolution, air photo specifications, air photo, interpretation

Silver sagebrush (Artemisia cana-Pursch) has a ubiquitous presence on the Great Plains of North America. Its occurrence has led to strategies ranging from eradication to conservation and protection. It is a common native shrub, characteristic of the dry mixed grass natural region of

Author would like to thank Dr. R.J.Hall for preliminary review of the manuscript and Mr. L. Fitch for providing general guidance and encouragement for this project.

Manuscipt accepted 19 Apr. 1998.

\section{Resumen}

Las fotografís aéreas en Alberta son generalmente adquiridas de acuerdo al mapeo topográfico y especificaciones forestales. Los parametros para interpretar la vegetación de pastizal, tal como "silver sagebrush" (Artemisia cana - Pursch), necesitan ser explorados y condensados en una especificación operacional. 7 fotointerpretadores evaluaron 5 tipos de pelíula area y 3 ángulos solares para determinar las condiciones óptimas para interpretar el "silver sagebrush" a una escala de 1:20,000. La exactitud y preferencia del interpretador son determinadas para las dos condiciones experimentales, así como para determinar la especificaciones operacionales. La película Kodak Panatomic-X 2412 logró la mayor exactitud de interpretación para la detección de la cobertura y densidad de plantas de "silver sagebrush" $(91.0 \%$ y $94.4 \%$ respectivamente), en tanto Kodak Aerochrome Infrared 2443 y Agfa Avicolor $\mathrm{H100}$ fueron mejores para estimar el vigor de la planta (97.2\% y 93.7\% respectivamente). Los fotointerpretadores también escogieron la película Kodak Panatomic- $X$ 241 como la mejor para interpretar el "silver sagebrush" (7.7 en base a una escala de 10). Se obtuvieron correlaciones positivas entre combinaciones de exactitud de intrepretación , perferencia del tipo de película del fotointerpretador y las medidas del rango de densidad fortográfica, indicando las tendencias que una mayor exactitud y preferencia estan asociadas con los rangos de densidad mayores. Los ángulos solares de $20^{\circ}, 37^{\circ}$ y $54^{\circ}$ fueron evaluados por los fotointerpretadores los cuales tuvieron una preferencia por el ángulo de $20^{\circ}$. Se proponen recomendaciones para modificar las especificaciones operacionales de la fotografía area de Alberta para incluir imagnes de alta resolución (Kodak Panatomic-X) y disminuir de $30^{\circ}$ a $20^{\circ}$ el límite inferior operacional del ángulo solar para interpretar "silver sagebrush" en la escala de 1:20,000. mentaron en promedio 0.5 y $1.2^{\circ} \mathrm{C}$ respectivamente.

Alberta (Achuff 1994). It also defines the habitat conditions for a range of wildlife species such as pronghorn antelope (Antilocarpa americana) and sage grouse (Centrocercus urophasianus) (Mitchell and Smoliak 1971, Wallestad 1976, Glaholt 1984, Kerley and Anderson 1995).

Silver sagebrush is a short shrub with typical heights around 0.25 to $0.75 \mathrm{~m}$, but heights of 1.0 to $1.5 \mathrm{~m}$ are not 
uncommon in ideal soil moisture conditions. It tends to grow in mesic sites where it is often found in fairly dense distributions. The presence and abundance of silver sagebrush can reduce the production of associated grasses and forbes (White and Currie 1983, 1984). The shrub is also commonly found in low lying level, poorly drained clay soils and saline areas (Smoliak et al. 1981). In Alberta, it is frequently associated with the Orion (ORN) soil series (Contract PedologyLethbridge, personal communication, 1997), and is also the dominant species of sagebrush flats (Wershler and Wallis 1986). Silver sagebrush can usually be identified by its distinctive light blue-green and silvery hue that contrasts sharply among the greener or yellow-brown grasses and shrubs (depending on the moisture situation) on the prairie landscape (Wilkinson 1990).

The interest in the plant, whether for wildlife habitat preservation or for agricultural efficiency, has led investigators to explore various means for identifying and mapping its distribution on rangelands. Aerial photographs remain the most used and the highest resolution product able to capture the spatial and textural characteristics of the scene (Tueller 1989, Driscoll 1992). Although aerial photographs remain the traditional remote sensing tool, the technology associated with it has not been stagnant. Improvements in films, cameras, and lens have been particularly vigorous over the past 10 years (Fent 1990, Bahnmüller 1992, Fent and Brouwer 1993, Mussio and Light 1995, Light 1996).

The application of these advancements and innovations in aerial photography have been investigated to some degree in forestry (Hall and Fent 1991, Fent et al. 1995), however, specific details in optimizing aerial photographic product performance for identifying silver sagebrush (and for other rangeland applications) have been limited to large scale photographic studies (Nesby 1986, Werth and Work 1991). In addition to the spectral influences of aerial films in detecting silver sagebrush, other photographic variables will also impact the shrub's photographic recording identity. Image contrast, varied either photographically or by solar angle, has a major effect upon the quality of photo interpretation (Welch and Halliday 1975). Furthermore, human preference for specific film or contrast may also be an influencing factor in air photo interpretation (Hall and Fent 1991).

The objective of this study was to investigate whether 2 photographic variables, film type and contrast change associated with different solar angles, are factors in detecting and classifying silver sagebrush distributions. The study objective was addressed by the following 3 questions: is there a film type that leads to greater accuracies in interpreting silver sagebrush; is there a film type that is more preferred by interpreters for interpreting silver sagebrush, and; is solar angle a factor for air photo interpretation of silver sagebrush?

\section{Study Area}

The study area is located in Township 1 Range 2 west of 4 meridian in the southeast corner of the province of Alberta and adjacent to Montana (National Topographic System map sheets $72 \mathrm{E} / 1)$. It is located within the Dry Mixed Grass Ecoregion (Strong and Leggat 1981). A north-south $12 \mathrm{~km}$ flight line was flown along Sage Creek to capture a wide diversity in silver sagebrush distribution, density, and vigor.

\section{Materials and Methods}

\section{Aerial Photography}

The 5 aerial films ${ }^{1}$ selected are described in Table 1 (Agfa-Gevaert 1990a, 1990b; Eastman Kodak 1992). The Kodak Aerographic Infrared 2424 (BWIR) is a near-infrared sensitive aerial film with a spectral sensitivity extending to approximately $900 \mathrm{~nm}$. Agfa Aviphot Pan 50 (A50) and Kodak Panatomic 2412 (PANX) are

\footnotetext{
${ }^{1}$ The mention of trade names does not imply endorsement by the author.
}

classed as extended red sensitivity films with spectral sensitivities extending to approximately 750 and $720 \mathrm{~nm}$, respectively (Table 1). The Agfa Avicolor H100 (H100) is a true color film manufactured by Agfa while the Kodak Aerochrome Infrared 2443 (CIR) is a standard false color infrared film manufactured by Kodak. Table 1 also outlines the spatial resolution of the aerial films; PANX and A50 are regarded as high resolution films while the other emulsions are general purpose films.

The aerial photography was acquired at 2 separate times. The first acquisition occurred on 14 July 1996 with all films flown at a scale of 1:20 000. The 5 films were flown and exposed with a forward motion compensation (FMC) equipped metric aerial camera (Zeiss Jena) and with minimal rate change in the solar angle $\left(54^{\circ}\right.$ $\pm 1^{\circ}$ ). Processing was conducted with the same processor (Kodak Versamat II) and chemicals (Kodak 885) for the black-and-white films. The color films were processed in their own respective processing environments (EA-5 for CIR and C-41 in high color saturation mode for H100). The contrast of the black-and-white films was further controlled sensitometrically by processing all the films to an average gradient of $1.40^{2}$ and printing the negatives on grade 3 paper. The CIR film was sensitometrically evaluated to determine its IR balance value (Fleming 1979) and exposed such that an IR balance of 28 was achieved to compensate for altitude and inherent infrared film sensitivity. All films except the H100 were exposed with a minus blue $(500$ $\mathrm{nm}$ ) cutoff filter to reduce haze effects, the $\mathrm{H} 100$ was exposed with a $420 \mathrm{~nm}$ haze compensating filter. These considerations served to reduce the effect of image motion, variable contrast, and film processing that would otherwise mask the differences among films and affect interpretation accuracies.

\footnotetext{
${ }^{2}$ Average gradient $(\mathrm{G})$ defines the ratio of the brightness range of objects photographed on the ground and the photographic density measured on the negative (International Standards Organization 7249, 1986). A brightness range to density ratio of $1: 1$ equals an average gradient of 1.0. An average gradient of 1.4, therefore, indicates that the photographic contrast (or density range) was enhanced by $40 \%$ relative to the ground contrast.
} 


\begin{tabular}{|llccc|}
\hline \multicolumn{7}{ll|}{ Table 1. Aerial films investigated and some defining characteristics. } \\
\hline \hline Films & Type & Abbreviation & $\begin{array}{c}\text { Film } \\
\text { Resolution } \\
\text { (lp/mm) }\end{array}$ & $\begin{array}{c}\text { Spectral } \\
\text { sensitivity } \\
\text { (nm) }\end{array}$ \\
\hline Kodak Infrared Aerographic 2424 & black and white & BWIR & 50 & 900 \\
Agfa Aviphot Pan 50 & black and white & A50 & 81 & 750 \\
Kodak Panatomic Aerographic II 2412 & black and white & PANX & 125 & 720 \\
Agfa Avicolor H 100 & color & H100 & 40 & 670 \\
Kodak Aerochrome Infrared 2443 & color & CIR & 32 & 900 \\
\hline & & & & \\
\hline
\end{tabular}

\section{Interpretation Procedure}

The second air photo acquisition phase occurred on 8 July 1997 using the same camera and scale. The best performing film from the phase 1 analysis (PANX) was flown at 3 distinct solar angle conditions, $20^{\circ} \pm 0.5^{\circ}$, $37^{\circ} \pm 0.5^{\circ}$, and $54^{\circ} \pm 0.5^{\circ}$, providing 3 unique solar angle contrast conditions to evaluate. The average gradient (1.40) and paper grade (3) were controlled to isolate the contrast changes due to solar angle. The 2 phase experimental design was deemed necessary to adequately control the continuously changing environmental light conditions.

Thirty-two polygons were selectively chosen along the flight path and among the different films for the interpretation procedure. The polygons varied in silver sagebrush coverage, density and vigor. This ensured each film type was represented by different polygons, and prevented photo interpreters interpreting the same stand more than once. Seven interpreters from various government and private agencies familiar with rangeland photo interpretation participated in the first phase of the study. The interpreters were asked to identify silver sagebrush for each of the polygons outlined on the aerial photographs by primarily noting the percentage of sagebrush covering the polygon and

also stratifying the cover by density (in stems/ha) and plant vigor. Each of these 3 attributes were classed in 6 percentage intervals; the interpreter was asked to choose which of the 6 classes best represented the attribute in question (Table 2). The interpreters were provided with a photo interpretation key of silver sagebrush at a 1:20 000 scale as means to train themselves in recognizing the various silver sagebrush attributes. The ground reference information was obtained from field surveys of each of the 32 chosen polygons (used to determine vigor qualities) and from $35 \mathrm{~mm}$ reconnaissance photographs taken from a helicopter at a scale of 1:500 (use to determine density and ground cover percentage). The ground reference information was also categorized using classes described in Table 2.

\section{Data compilation and statistical analysis}

Interpretation accuracy was determined by calculating the difference between the interpreters' interpretation class of an attribute and the ground reference class. The difference indicated the number of classes the interpreter deviated from the ground truth (Fent et al. 1995). Since each of these classes were approximately $16.7 \%$, an interpretation accuracy value $\left(\mathrm{A}_{\mathrm{i}}\right)$ could be calculated by the

\begin{tabular}{|lll|}
\hline \multicolumn{2}{|l|}{ Table 2. Silver sagebrush attributes that interpreters were requested for each of the 32 polygons. } \\
\hline \hline Coverage Class & $\begin{array}{l}\text { Density Classes } \\
\text { (stems/hectare) }\end{array}$ & Vigor Classes \\
\hline $0=$ no sagebrush & $0=$ no sagebrush & $0=$ no sagebrush \\
$1=1-20 \%$ & $1=\leq 500$ & $1=$ dead \\
$2=21-40 \%$ & $2=501-1000$ & $2=$ poor \\
$3=41-60 \%$ & $3=1001-2000$ & $3=$ average \\
$4=61-80 \%$ & $4=2001-4000$ & $4=$ good \\
$5=81-100 \%$ & $5=\geq 4001$ & $5=$ excellent \\
\hline
\end{tabular}

following formula:

$$
A_{i}=100-\left(\left(\left|I_{i}-G_{i}\right|\right) 16.7\right)
$$

where

$\mathrm{I}_{\mathrm{i}}=$ Interpreted class value

$\mathrm{G}_{\mathrm{i}}=$ Ground reference class value

The 7 photo interpreters, interpreting 3 cover attributes, for 32 polygons created a database of 672 accuracy values which were then stratified by film type. A one-way analysis of variance (ANOVA) was conducted on the balanced data set (Table 3) and the Tukey multiple means comparison (SAS Institute 1985, Neter et al. 1990) was employed to determine if there were significant differences among the films (Table 4).

Interpreters were also asked to rank each of the film combinations for preference on a scale of 1 to 10 with the high score indicating high preference. The preference values were averaged and ranked, and associated to film interpretation accuracy and density range rankings. The ranks were analyzed using Spearman's Rank Correlation Coefficient $\left(\mathrm{r}_{\mathrm{s}}\right)$ (Mosteller and Rourke 1973). The phase 2 data compilation required interpreters to rank the PANX flown at the 3 different solar angles. Five additional interpreters (total 13) participated in this process and the results were compared and analyzed for statistical significance using the Friedman Statistic $\left(\chi_{\mathrm{r}}^{2}\right)($ Mosteller and Rourke 1973) .

\section{Results and Discussions}

\section{Interpretation Accuracy}

The first question of this study was to determine which of the 5 films performed best when silver sagebrush cover, density, and vigor were interpreted. PANX was the highest performing film for interpreting silver sagebrush ground cover and density (Table 4), while the color films performed best when interpreting vigor (Table 4). PANX is distinguished from the other films by its superior resolution and apparently aids the interpreter in detecting and assessing the distribution of silver sagebrush. The relatively small scale $(1: 20000)$ of the interpre- 
Table 3. Analysis of variance table for the films evaluated.

\begin{tabular}{|lcccc}
\hline \hline Dependent variable & Source & Degrees of Freedom & F value & Pr $>$ F \\
\hline Coverage & Film & 4 & 26.61 & 0.0001 \\
Density & Film & 4 & 39.76 & 0.0001 \\
Vigor & Film & 4 & 20.71 & 0.0001 \\
\hline
\end{tabular}

tation images may also favor a high resolving film such as PANX in detecting a small shrub such as silver sagebrush. The increase in interpretation accuracy associated with PANX is also noted in applications associated with forestry and photogrammetry (Becker 1988, Fent et al. 1995, Hall and Fent 1996). The higher results produced by CIR and H100 for interpreting plant vigor (Table 4) were not

\begin{tabular}{|c|c|c|c|}
\hline Variable & Tukey Grouping & Mean & Film \\
\hline Coverage & 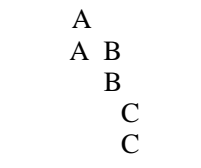 & $\begin{array}{l}91.0 \\
86.9 \\
85.4 \\
78.3 \\
77.7\end{array}$ & $\begin{array}{l}\text { PANX } \\
\text { A50 } \\
\text { CIR } \\
\text { H100 } \\
\text { BWIR }\end{array}$ \\
\hline Density & $\begin{array}{l}\text { A } \\
\text { A } \\
\text { B } \\
\text { B } \\
\quad \text { C }\end{array}$ & $\begin{array}{l}94.9 \\
91.0 \\
80.2 \\
79.1 \\
69.5\end{array}$ & $\begin{array}{l}\text { PANX } \\
\text { A50 } \\
\text { CIR } \\
\text { BWIR } \\
\text { H100 }\end{array}$ \\
\hline Vigor & $\begin{array}{l}\text { A } \\
\text { A } \\
\text { B } \\
\text { B } \\
\text { C }\end{array}$ & $\begin{array}{l}93.7 \\
92.7 \\
85.2 \\
84.4 \\
78.1\end{array}$ & $\begin{array}{l}\text { H100 } \\
\text { CIR } \\
\text { PANX } \\
\text { BWIR } \\
\text { A50 }\end{array}$ \\
\hline
\end{tabular}

unexpected given the phenological properties of the plant in mid-summer. The vigor attribute is highly dependent on the plant's leaf reflective properties which are at optimum condition during the growing season (White and Currie 1984). Films that add a color dimension, such as the CIR and H100 have an inherent advantage over the black-and-white films in portraying hue differences. Moreover, a film such as CIR that has both color and infrared sensitivity, will have an added advantage over other films in detecting plant health attributes. The overall results suggest that PANX is the best film for assessing quantity attributes while the color films are better tools for assessing quality attributes.

\section{Interpreter Film Preference}

The second question in this study was to determine whether interpreter preference differed among the film types. The most preferred film was PANX, with the A50 and CIR also showing relatively high preference as noted by the $95 \%$ confidence interval bars in Figure 1. The least preferred films were the H100 and the BWIR. These results suggest that the superior resolution characteristics of PANX and A50 (125 and $80 \mathrm{lp} / \mathrm{mm}$, respectively) are an important factor in the interpreter's assessment of 'good' quality or ease of interpreting sagebrush. In addition, slower speed and sharper films tend to have more contrast giving a further impression of sharpness and increased subjective preference (Pfenninger 1984). Although the resolution quality of CIR is relatively low, this film's higher ranking was most likely associated with its infrared sensing and color rendition qualities. It should be noted, however, that this film also showed the greatest ranking variation as indicated by the $95 \%$ confidence interval bars in Figure 1. The H100, although a color film, may be disadvantaged at a scale of 1:20 000 because of poor haze penetration abilities, while other films fare better in this regard due to either haze filtration or infrared sensitive properties. Haze will reduce contrast, detail, and apparent sharpness in aerial photographs leading to a lower preference rating.

BWIR's poor ranking may be associated with the phenology of silver sagebrush plant relative to the general reflective character of its immediate environment. The reflective characteristics of the light green-silvery hues of the leaves are an atypical feature of this plant and show a gradual and quasi-linear increase from the blue to the infrared portion of the electromagnetic spectrum (Tueller 1989). Most vegetation shows a defined 'red edge' where the infrared reflective portion is abruptly higher than the visible reflective component (Brandes 1994). It is this contrast between the visible and the infrared reflective character of plants that aids photo interpreters in identifying vegetative characteristics. In silver sagebrush, this marked difference is subdued and further reduced because the near infrared reflective character of the surrounding grasses is relatively low, especially when they are in the maturity stage or under water stress. The lack of spectral contrast among ground vegetation, the relatively lower resolution of the film, and the lack of color (CIR's advantage) all may be factors associated with BWIR's perceived non-utility in silver sagebrush interpretation.

\section{Accuracy-Preference-Density Range}

The photographic density range of an image is a good indicator of the image's contrast. The density range of the experimental film images will vary because image contrast in this experiment is being determined exclusively by the films' spectral attributes. These contrast differences provide further evidence for deciphering the film accuracy and preference results. Spearman's Rank correlation results (Table 5) indicate a positive $\left(\mathrm{r}_{\mathrm{s}}=0.90\right)$ and significant $(\mathrm{P}<0.05)$ trend between density range and preference. Density range and accuracy correlations were also positive $\left(r_{s}=0.80\right)$ but insignificant $(P>0.10)$. Positive and significant correlations were, however, noted between interpreter preference and accuracy $\left(\mathrm{r}_{\mathrm{s}}=0.90, \mathrm{P}<0.05\right)$. These correlated trends suggest that interpreters are noting contrast as an interpretation aid influencing both interpreter preference and accuracy. Contrast variations in this experiment were attributable to the spectral differences between films; however, defining an ideal contrast requires that average gradient and paper grade variables also be investigated and related to the density range parameter. 


\section{Solar Angle Contrast}

The third question in this study was to investigate whether solar angle was a factor in the interpretation of silver sagebrush. Interpreter assessments showed a highly significant preference $(\mathrm{P}<0.01)$ for the images flown at a solar angle of $20^{\circ} \pm 0.5^{\circ}$ followed by the $37^{\circ} \pm 0.5^{\circ}$ and the $54^{\circ} \pm 0.5^{\circ}$ images (Fig. 2). The enhanced contrast resulting from longer shadows accentuates the vegetative and topographic ground pattern and allows the interpreter a better textural context for identifying silver sagebrush distribution. The shadow information also provides the interpreter with cues on appraising shrub height that would not be photogrammetrically possible given the minimal image displacement at the scale of the photo. The solar angle photo samples in Figure 3 depict this effect.The relatively low solar angle preferred by the interpreters, however, should be considered with some degree of caution. The topographic character of the landscape may be a factor in obscuring land detail where slopes greater than $20^{\circ}$ are encountered and the practicalities of flying with such a restricted solar angle may not be economically feasible. In essence, the decision to fly at lower solar angles should acknowledge the enhancements of textural and topographic detail, but be wary of both the length of time required to fly the project and the terrain morphology.

\section{Conclusion}

The results of this study indicate that, at a scale of 1:20 000, PANX film $(\mathrm{G}=1.40)$ flown at relatively low sun angles provides the best results for interpreting silver sagebrush cover and density, with color films showing an advantage for interpreting plant vigor. These findings suggest that a modification in air photo specifications for rangeland applications, silver sagebrush inventory in particular, may be warranted in Alberta.

The recommended use of PANX, implies that higher spatial resolution and contrast, rather than spectral sensitivity, is the key factor in detecting

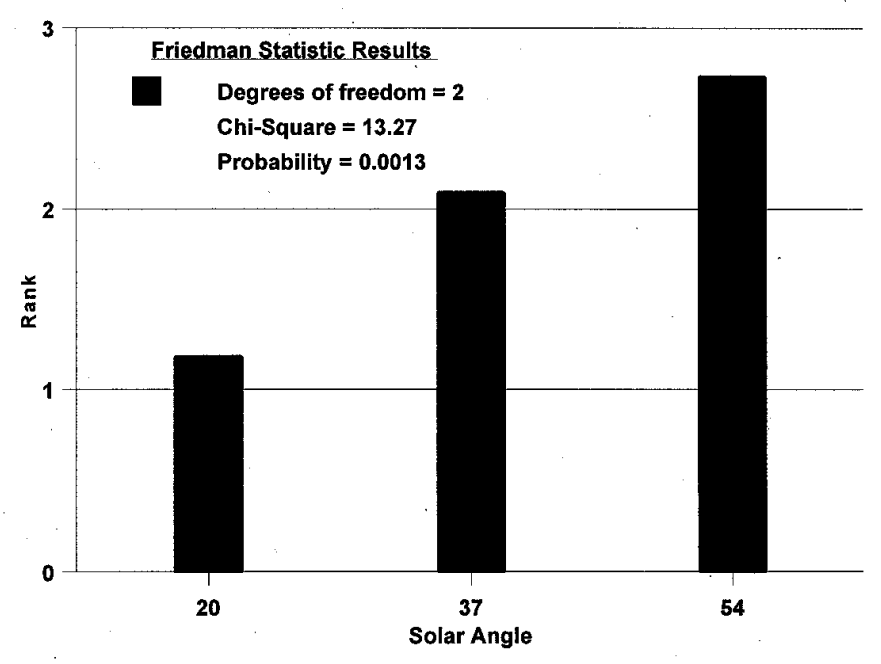

Fig. 1. Mean interpreter preference ranks with $95 \%$ confidence intervals the higher resolving films (PANX, A50) is indicated. CIR also shows relatively high preference but with more variation (less agreement among interpreters).

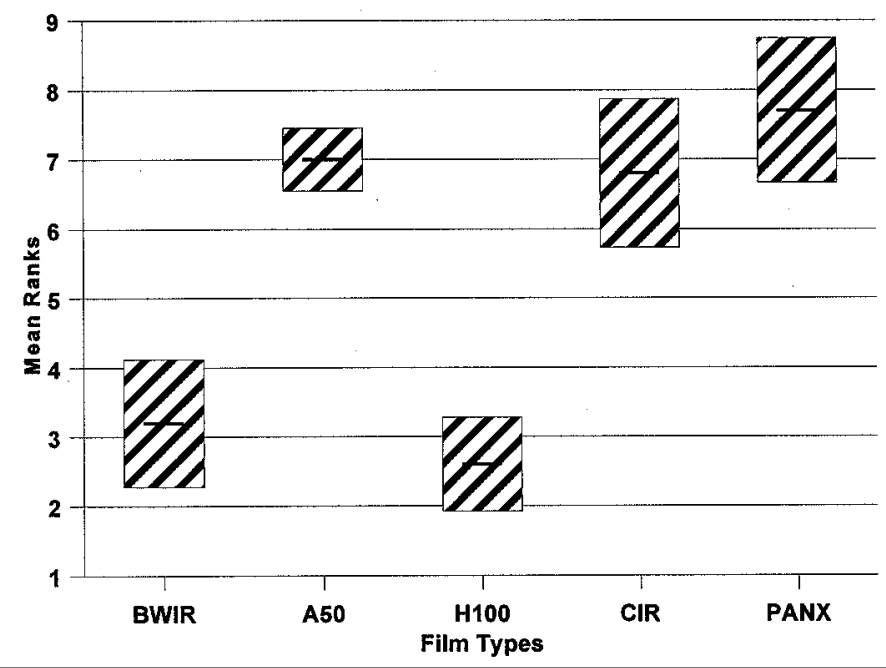

Fig. 2. Mean interpreter preference ranks of the PANX flown at the 3 different solar angles. The highly significant results $(\mathrm{P}<0.01)$ indicate that interpreter preference increases as the solar angle decreases.

Table 5. Values for interpretation accuracy ${ }^{1}$, preference and density range ${ }^{2}$ are ranked and analyzed $^{3}$ for each film type.

\begin{tabular}{lccccccc}
\hline \hline Film & \multicolumn{2}{c}{ Preference } & \multicolumn{2}{c}{ Interpretation accuracy } & \multicolumn{2}{c}{ Density range } \\
\cline { 2 - 8 } & Value & Rank & Value & Rank & Value & Rank \\
\hline BWIR & 3.2 & 4 & 78.2 & 5 & 0.30 & 4 \\
A50 & 7.0 & 2 & 81.1 & 3 & 0.54 & 3 \\
PANX & 7.7 & 1 & 90.4 & 1 & 0.76 & 1 \\
H100 & 2.6 & 5 & 80.5 & 4 & 0.18 & 5 \\
CIR & 6.8 & 3 & 86.7 & 2 & 0.68 & 2 \\
\hline
\end{tabular}

${ }^{1}$ Mean of the cover, density, and vigor accuracy values for each film

${ }^{2}$ Status $\mathrm{M}$ densiometry, visual filtration (1 $\mathrm{mm}$ aperature)

${ }^{3}$ Spearman's Correlation Coefficients:

$$
\begin{array}{lll}
\text { Preference X Interp. accuracy } & \mathrm{r}_{\mathrm{s}}=0.90 & \operatorname{Pr}=0.0374 \\
\text { Preference X Density range } & \mathrm{r}_{\mathrm{s}}=0.90 & \operatorname{Pr}=0.0374 \\
\text { Interp accurancy X Density range } & \mathrm{r}_{\mathrm{s}}=0.80 & \operatorname{Pr}=0.1041
\end{array}
$$




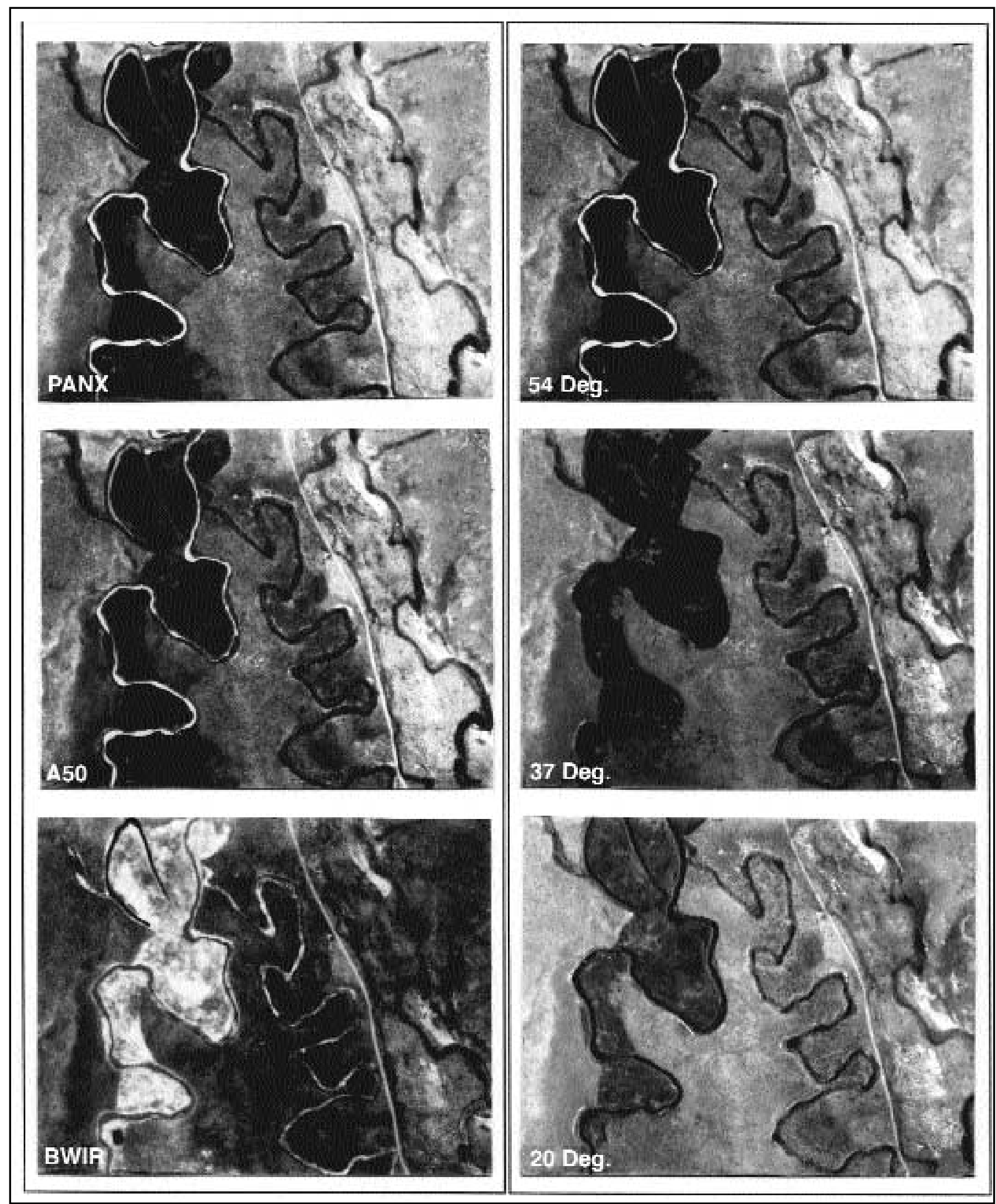

Fig. 3. A part of the study area as depicted by the 3 black-and-white films (left) and the 3 solar angle conditions using PANX (right). Significant occurrences of silver sagebrush are located along the dry creek bed along the center of the photos. The $20^{\circ}$ solar angle condition is the only instance where the textural detail is sufficiently enhanced to show individual stands of silver sagebrush. 
silver sagebrush at a scale of 1:20 000 . Because this film is relatively low in sensitivity (40 ISO A), image motion effects must be addressed.

FMC cameras, thus, become essential in exploiting the film's resolution characteristics.

The interpreter preference for a lower solar angle needs to be implemented carefully. Adopting a lower solar angle would entail a change from the minimum current value in Alberta of $30^{\circ}$ to about $20^{\circ}$. Values lower than $20^{\circ}$ would be impractical because of extreme shadows and low lighting conditions (especially when PANX is considered). The maximum value is defined only in that it should be below the second most preferred experimental level of $37^{\circ} \pm 0.5^{\circ}$. A working range of $20^{\circ}$ to $35^{\circ}$, with the understanding that the higher end values will diminish interpretability and lower end values may obscure some slope information is suggested. The operational range cannot be too narrow otherwise flying time is compromised.

The results and recommendations proposed suggest a modification in acquiring aerial photography for rangeland applications, or at least a consideration of the factors that will aid vegetation interpretation in prairie environments when relatively small scales are used. Optimizing these photographic factors should lead to more accurate initial stratifications of vegetation and more efficient methods for inventories of silver sagebrush.

\section{Literature Cited}

Achuff, P.L. 1994. Natural regions, subregions, and natural history themes of Alberta. Alberta Environmental Protection. Edmonton, AB.

Agfa-Gevaert N.V. 1990a. Aviphot Pan 50 PE1 technical information. Agfa-Gevaert N.V. Mortsel, Belgium 789(Li).

Agfa-Gevaert N.V. 1990b. Aviphot Color H 100 PE1 technical information. AgfaGevaert N.V. Mortsel, Belgium 6030/Li.

Bahnmüller, W. 1992. Aviphot black and white films - sensitization and modulation transfer function. In: Proc. of International Society for Photogrammetry and Remote Sensing, XVII Congress, Vol. XXIX, Part B 1, Commission I, Washington, D.C.Becker, R. 1988. Very high resolution aerial films. Photogrammetria, 42:283-302
Brandes, J. 1994. Black and white aerial film characteristics: a primer. Earth Observation Magazine 3(10):49-50.

Driscoll, R.S. 1992. Remote sensing- an invaluable ally for assessing and managing renewable natural resources. GIS World 5(4):66-69.Eastman Kodak. 1992. Kodak data for aerial photography. Publ. No. AS29. Rochester, N.Y.

Fent, L. 1990. A more discriminating use of aerial photographic emulsions and processing techniques. In: Proc. Symp. on Global and Environ. Monitoring, Techniques and Impacts. ISPRS Comm. VII. Victoria, BC.

Fent, L. and J.M. Brouwer. 1993. Evaluation of four color negative aerial films. State-of-the-Art Mapping. In: Bill P. Clark, Andy Douglas, Brian L. Foley, Brian Huberty, LeLand D. Whitmill, Ed(s). Proc. SPIE 1943:164-171.

Fent L., R. J. Hall, and R. K. Nesby. 1995. Aerial films for forest inventory: optimizing film parameters. Photogramm. Eng. Remote Sensing 61:281-289.

Fleming, J.F. 1979. Standardization techniques for aerial color infrared film. Interdepartmental Committee on Air Surveys. Ottawa, Canada.

Glaholt, R.D. 1984. Availability of critical pronghorn antelope habitat in southern Alberta and its relation to land use. M.Sc. Thesis Univ. Calgary, Calgary, AB.

Hall, R.J. and L. Fent. 1991. Relating forestry interpreter preference to sensitometric parameters of black and white and normal color aerial films. ISPRS J. Photogramm. Remote Sensing 46:328-345

Hall, R.J. and L. Fent. 1996. Influence of aerial film spectral sensitivity and texture on interpreting images of forest species composition. Can. J. Remote Sensing 22:350-359.

International Standards Organization 7829. 1986. Photography-black and white aerial camera films determination of ISO and average gradient. International Organization for Standardization. Ref. No. ISO 7829-1986(E).

Kerley L.L. and S.H. Anderson. 1995. Songbird responses to sagebrush removal in a high elevation sagebrush steppe ecosystem. Prairie Naturalist. 27:129-146

Light, D.L. 1996. Film cameras or digital sensors? The challenge ahead for aerial imaging. Photogramm. Eng. Remote Sensing 62:285-291.

Mitchell, G.J. and S. Smoliak. 1971. Pronghorn antelope range characteristics and food habits in Alberta. J. Wildl. Manage. 35:238-250.

Mosteller, F. and R.E.K. Rourke. 1973. Sturdy statistics: nonparametrics and order statistics. Addison-Wesley, Reading, Mass.
Mussio, L. and D.L. Light. 1995. ISPRS Commission I: sensors, platforms, and imagery symposium. Photogramm. Eng. Remote Sensing 61:1339-1344.

Nesby, R.K. 1986. Interpretation of native range vegetation from 1:500 $70 \mathrm{~mm}$ large scale color and color infrared photography. Resource Evaluation and Planning, Alberta Forestry, Lands and Wildlife, Rep .No. RIB 115. Edmonton, AB.

Neter, J.W., W. Wasserman, and M.H. Kutner. 1990. Applied linear statistical models. Third Ed., Irwin, Boston, Mass.

Pfenninger, U. 1984. Image quality evaluation by subjective and objective criteria of sharpness and gradation with $\mathrm{b} / \mathrm{w}$ transparencies. J. Photo. Sci. 32:207-217.

SAS Institute Inc. 1985. The ANOVA procedure. SAS Users Guide: Statistics. SAS Institute Inc. Cary, N.C.

Smoliak, S.A., A. Johnson, M.R. Kilcher, and R.W. Lodge. 1981. Management of prairie rangeland. Agr. Can.. Publ. No.1589.

Strong W. and K.R. Leggat. 1981. Ecoregions of Alberta. Alberta Energy and Natural Resources. ENR Tech. Rep. No. T/4. Edmonton, AB.

Tueller, P.T. 1989. Remote sensing technology for rangeland management applications. J. Range Manage. 42:442-452.

Wallestat, R. 1976. Sage grouse: threatened species? Montana Outdoors, Sept./Oct.

Welch, R. and J. Halliday. 1975. Image quality controls for aerial photography. Photogramm. Rec. 8:317-324.

Wershler, C. and C. Wallis. 1986. Lost river significant features assessment. Alberta Forestry Lands and Wildlife. Tech. Rep. T/123, Edmonton, AB.

Werth, L.F. and E.A. Work Jr. 1991. Inventory and monitoring coordination guidelines for the use of aerial photography in monitoring. US Dept. of the Int., BLM, Tech. Ref. 1734-1, Denver, Colo.

White R.S., and P.O. Currie. 1983. The effects of prescribed burning on silver sagebrush. J. Range Manage. 36:611-613.

White R.S., and P.O. Currie. 1984. Phenological development and water relations in plains silver sagebrush. J. Range Manage. 37:503-507.

Wilkinson, K. 1990. Trees and shrubs of Alberta. Lone Pine Publishers, Edmonton, $\mathrm{AB}$. 